DOI 10.37882/2223-2982.2020.08.06

\title{
К ВОПРОСУ О НЕКОТОРЫХ СЕМАНТИЧЕСКИХ ОСОБЕННОСТЯХ АНГЛИЙСКОЙ ТЕРМИНОЛОГИИ ПРАВА
}

\section{TO THE QUESTION OF SOME SEMANTIC FEATURES OF THE ENGLISH TERMINOLOGY OF LAW}

\section{G. Bikbulatova}

Summary: The article is devoted to some semantic features of the English terminology of law. Questions related to the English-language terminology of law are currently one of the most relevant and interesting for both researchers and teachers of law schools.

Keywords: development of international contacts, terminology of law, borrowings, legal system, foreign language training, term system, professional communication.

\author{
Бикбулатова Гузель Ханифовна \\ старший преподаватель, Уфимский юридический \\ институт МВД России \\ g.bikbulatova@azelux.ru
}

Аннотация: Статья посвящена вопросу семантических особенностей английских юридических терминов. Вопросы, связанные с англоязычной терминологией права в настоящее время являются одними из наиболее актуальных и интересных как для исследователей, так и для преподавателей юридических вузов.

Ключевые слова: развитие международных контактов, терминология права, заимствования, правовой системе, иноязычная подготовка, терминосистема, профессиональное общение.
$\mathrm{P}$ азвитие международных контактов, а также стремительно меняющаяся политическая ситуация в мире создают необходимость в профессиональном, адекватном и взаимовыгодном диалоге на различных уровнях общения, так как для достижения взаимопонимания необходимо, чтобы информация, которой обмениваются участники общения, передавалась и воспринималась максимально полно и точно. В связи этим, вопросы, связанные с англоязычной терминологией права в настоящее время являются одними из наиболее актуальных и интересных как для исследователей, так и для преподавателей юридических вузов.

Английский язык играет особую роль, как в мировой политике, так и в области права, поскольку он широко распространён и используется при общении представителей различных национальностей. Англоязычные юридические термины активно используются юристами и учеными не только при ведении переговоров и в публичных выступлениях, но и в основополагающих правовых и политических документах.

Следовательно, изучение различных подсистем английского языка, в данном случае, системы юридической терминологии, приобретает особое значение. Термины, используемые в сфере юридической системы, находят широкое применение не только в сфере юриспруденции, но и в других сферах языковой коммуникации. Это свидетельствует о том, что юридическая терминология имеет широкое распространение.

Согласно Лингвистическому энциклопедическому словарю, юридические термины представляют собой лексемы, используемые при изложении основного содержания законных актов и иных нормативных юридических документов [8, с. 76]. Отметим, что лексические единицы, используемые при составлении законодательной базы, представляют собой обобщенные наименования юридических терминов, которые в свою очередь являются однозначными и функционально устойчивыми $[6$, c. 87].

Необходимо подчеркнуть, что юридическая терминология способствует не только более точному изъяснению законодательных актов, но и возможности достижения краткости, сжатости и односложности юридических текстов. Незначительный объем текста нормативной базы способен передать необходимый смысл исследуемого текста.

Главной особенностью терминологии права, как языка профессиональной коммуникации, является ориентация на понимание языковой картины мира населения, а также выявление особенностей политических и юридических теорий, научных направлений и правового опыта [7, с. 98].

Основная база терминологии права содержится в наиболее значимых законах и нормативных правовых актах, которые и определяют своего рода эталоны терминологии права, и на которые ориентируются правотворческие органы. Конституция является источником основополагающих юридических терминов.

Наиболее важной характеристикой юридической терминологии является её распространенность. Как из- 
вестно, право и нормативная база используется в различных сферах жизни. Предметом правового регулирования являются различные социальные взаимосвязи, которые возникают в общественной жизни.

Поэтому в нормативно-правовых документах используется как бытовая лексика, так словарный состав самых различных отраслей знания, такие как медицина, техника, языкознание и другие, включая правовую терминологию.

Такая характеристика как постоянство является необходимым условием стабильности словарного запаса законодательства. Но, как и все явления в мире, язык подвержен изменениям. В первую очередь это отражается в процессе словообразования, так как это наиболее открытая и динамичная область в системе языка. Изменения, возникающие в языке и его словарном составе, касаются как семантики, так и процессов словообразования.

Отметим, что большая часть юридических терминов сохраняет свое значение и морфемный состав, не претерпевая существенных изменений. Однако, некоторые термины, которые не нашли употребление в законодательстве, выходят из употребления. Другими словами, одни термины заменяются другими, более точными, более употребительными, более точно отражающими то или иное явление или понятие.

Английская правовая система Общего права имеет богатую и содержательную историю своего развития. После вторжения в Англию герцога Нормандии и попытки завоевания страны была создана система Общего права в стране. Это способствовало оказанию влияния на становление и развитие правовой базы страны, а также других стран, находящихся под суверенитетом Британской империи.

Юридическая база Англии представляла собой сложную систему терминов, которая была закреплена в законодательных актах англосаксонских королей. Отметим отдельные группы терминов правовой системы Англии [1, с. 65].

В качестве примера можно привести группу терминов, служащих для обозначения денежных и имущественных штрафов, установленных в качестве компенсации за причиненные убытки или совершения преступлений:

- bot (компенсация потерпевшей стороне);

- half-leod (компенсация убитому лицу);

- wer-geld (имущество семьи человека, взятое в качестве компенсации за преступление);

- leod-geld (компенсация, которая выплачивалась королю и семье убитого в качестве компенсации за смерть).

В юридической системе Англии есть термины, обозначающие совершенные преступления:

- weg reaf;

- weg worte (грабеж);

- fore-steal (ограбление, сопровождаемое убийством).

Отметим термины, обозначающие правовые идеи защиты общественного порядка с применением оружия:

- bryce (защита от правонарушений);

- frith (право на защиту, предоставляемое людям в определенных районах, например церковному фриту).

Следует отметить, что в правовой системе Англии были не только перечисленные группы терминов.

В дальнейшем новые английские законы разрабатывались на основе юридических норм кодекса Юстиниана, получившего наименование corpus juris. Терминология права потеряла тесную связь с общим языком из-за влияния латыни. Она стала понятной только посвященным. Слова, перешедшие в правовую сферу из повседневного общения, получали свою, понятную только профессионалам, дефиницию. Вместе с этим появились лексемы, обозначающие общие, универсальные, искусственно созданные правила, которые было необходимо соблюдать всем членам общества, позже получившие статус закона.

В настоящее время нормативная база английской правовой системы включает в себя латинские заимствования, что доказывает важность законодательных актов английского права, заимствованных из римского права. В качестве примера можно привести следующие наименования: mens rea; actus reus (деяния подсудимого); ad valorem (в соответствии с ценой); habeas corpus (должен иметь тело); obiter dictum (статья закона) и др..

Нормандское завоевание привело к изменению англосаксонской правовой системы. В соответствии с этим, древнефранцузский язык стал преобладать в официально-деловой лексике, полностью вытеснив англосаксонский. Термины английского языка с использованием латинских заимствований были упразднены. Им на смену пришли французские аналоги.

Современная англоязычная юридическая терминология включает в себя следующие заимствования из французского языка: carte blanche (карт-бланш); droit (юридическое право); autrefois acquit (ранее приобретенный); rapprochement (сверка) и др..

Соответственно, французский язык приобрел статус 
проводника опосредованных латинских заимствований, семантика которых раскрывала термины прецедентного права, например: justice (правосудие); accuse (обвиняемый); cause (причина); jury (свидетели); plead (защищать в суде, ходатайство); heritage (наследование); marriage (брак); prison (тюрьма); appeal (апелляция, обжалование) ; felony (уголовное преступление) и др..

Обратимся к характеристике термина trespass, заимствованного из дневнефранцузского языка. Этот термин интересен тем, что он ввёл в английское право новую дефиницию: понятие «причинение вреда чужой собственности». После этого появилась система защиты права собственности. НА защите права собственности (trespass) строится английское и американское гражданское право.

В 1362 году Эдуард III издал приказ о ведении всех дел суда на английском языке. С этого времени английский язык получил статус государственного и стал распространяться на все законодательные акты. В качестве примера можно привести следующие понятия:

- legal aid (юридическая помощь);

- facts of crime (факты преступления) - corpus delicti (состав преступления);

- beyond powers - ultra vires (с превышением полномочий);

- donation gift (пожертвование) - donation mortis causa;

- lawsuit (иск) - lis;

- law of the place where the crime occurred (место преступления) - lex loci delicti;

- after the event (совершенное действие) - ex post facto;

— invoice - pro forma (формальный, ориентировочный);

- full bench (скамья подсудимых) - en bane и другие.

Английская юридическая терминология может включать в себя составные наименования, первая часть которых - прямое латинское заимствование, а вторая - английский термин или ассимилированное заимствование, например: pro forma letter (бланк письма); ad valorem duty (государственная пошлина); writ of habeas corpus (судебный приказ); action in rem (в действии); guardian ad litem (адвокат в действии) и др..

Кроме этого, английская правовая система включает в себя термины-интернационализмы греко-латинского происхождения, например: sodomy (содомия); prostitution (проституция); doctrine (доктрина, догма); precedent (прецедент) и другие.

Правовое законодательство Англии использует также термины- интернационализмы английского происхождения, например: lock out (заблокировать); warrant (предписание); good will (расположение) и др..

Терминология английской юридической системы представляет интерес, поскольку имеет синонимичные ряды. Существуют также абсолютные синонимы, образованные на базе английского языка и его диалектов:

mercy killing (эвтаназия) - euthanasia,

seizure - forfeiture (конфискация),

deceit (обман) - falserepresentation и др..

В некоторых случаях абсолютные синонимы могут отличаться лишь синтаксической структурой:

NaturalLaw - Law of nature (Закон природы),

Substantial law - Law of substance (Материальное право) и др.

Источником англоязычной терминологии права служат эвфемизмы, раскрывающие семантическое наполнение совершенных преступлений:

killing (убийство) - deprivation of life (лишение жизни) - blood (кровь),

death penalty (смертный приговор) - capital punishment (смертная казнь), др..

Правовая система Англии включает в себя синонимы, которые перешли из сферы делового общения:

hijacking (ограбление, нападение) - air piracy,

white knight - potential merger partner (потенциальный партнер, сообщник).

Следует отметить, что не все термины правовой системы являются семантически дублетными. В качестве примера можно привести «murder» и «assassination». Термин «assassination» употребляется в случаях использования киллеров (наемных убийц).

Кроме этого, в англосаксонской юридической системе существует пять лексем, обозначающих дефиницию «иск»: «action» (действие), «complaint» (жалоба), «claim» (запрос), «plea» (заявление), «lawsuit» (судебное дело). Мы приходим к выводу, что эти термины не являются абсолютными синонимами, поскольку каждая лексема имеет свои дополнительные оттенки значения.

Лексема «complaint» является дублетной по отношению к термину «сlaim». Однако полной синонимии в этих лексемах нет, потому что кажая из них многозначна: «suit» (ходатайство, иск, судебный процесс), «plea» (заявление), «action» (действие), «complaint» (жалоба), «claim» (запрос, заявка).

B «Словаре закона» лексема «action» употребляется в следующем значении: «A proceeding in which a party pursues a legal right in a civil court» (процесс, в котором сторона преследует законное право в гражданском суде) [5, c. 187]. 
Термин «suit» обозначает «... is commonly used for any court proceedings although originally it denoted a suit in equity as opposed to an action at law» (деятельность в рамках судебного разбирательства) [2, с. 123].

Это свидетельствует о том, что семантическое наполнение лексической единицы «suit» шире других определений синонимичного ряда. Мы приходим к выводу, что эти термины являются идеографическими.

Антонимия в юридической системе противопоставляет понятия «законный» и «незаконный». Такие термины достаточно ограничены в терминологии права:

legal (легальный) - illegal (нелегальный),

lawful (законный) - lawless (незаконный).

Таким образом, мы приходим к выводу, что английская терминология имеет достаточное количество заимствований из латинского и французского языка. Кроме этого, англосаксонская правовая система включает в себя комбинированные термины, состоящие из прямого латинского заимствования и английского термина или ассимилированного заимствования [7, с. 45].

Мы также отметили наличие в правовой сфере тер- минов-интернационализмов английского происхождения. Для юридической терминологии Англии характерна синонимия, представленная абсолютными синонимами, дублетами и терминами, которые не являются абсолютными синонимами. Употребление антонимии достаточно ограничено и сводится к значениям «законный» и «незаконный».

В современном мире каждый успешный специалист должен владеть английским языков, правовая система тоже не является исключением. Важно то, что в результате своего многовекового развития англо-американской правовой системе удалось выработать четкую и стройную систему «предъязыка» права, в которой установлены строгие соответствия между правовыми реалиями и терминами, их выражающими.

Исследование англоязычной юридической терминологии обусловлено острой нехваткой учебных пособий и словарей для специалистов права, характер работы которых связан с применением англоязычной юридической терминологии. Также существует необходимость подготовки специалистов, способных читать, понимать и переводить юридические тексты. Без специальных учебников и словарей, пособий такая задача трудновыполнима.

\section{ЛИТЕРАТУРА}

1. Алимов В.В. Теория перевода. Перевод в сфере профессиональной коммуникации. Учебное пособие. Изд. 3-е, стереотипное. - М.: Едиториал УРСС, 2005.

2. Большой юридический словарь. 3-е изд., доп. и перераб. / Под ред. проф. А.Я. Сухарева. - М.: ИНФА-М, 2007.

3. Иванова Г.А. 0 семантике и прагматике синонимичных терминологических сочетаний на материале русской лингвистической терминологии [Электронный ресурс]. - Режим доступа: http://www.russian.slavica.org/article3639.html.

4. Лейчик В.М. Культура термина [Электронный ресурс]. - Режим доступа: www.library.krasu.ru/ft/ft/_articles/0113944.pdf.

5. Лингвистический энциклопедический словарь. Глав. ред. В.Н. Ярцева. - М.: Научное изд-во Большая Российская энциклопедия, 2002.

6. Пиголкин А.С. Юридическая терминология и пути ее совершенствования. Ученые записки ВНИИСЗ. Вып.24 - М, 1971.

7. Прохорова В.Н. Полисемия и лексико-семантический способ словообразования в современном русском языке. Лекции по спецкурсу / В.Н. Прохорова. - М.: Изд-во Моск. ун-та, 1980. - 87 с.

8. Пумпянский А.Л. Введение в практику перевода научной и технической литературы на английский язык. - М.: Наука, 1964.

9. Суперанская А.В., Подольская Н.В., Васильева Н.В. Общая терминология: вопросы теории. - М.: Наука, 1989.

10. A Dictionary of Law. Sixth edition. Edited by Elizabeth A. Martin, Jonathan Law. Oxford University Press, 2006.

(с Бикбулатова Гузель Ханифовна (g.bikbulatova@azelux.ru). 